\title{
Grass intake and behaviour of young calves fed on pasture or zero-grazing
}

\author{
PaAvo Timonen ${ }^{1}$ ) \\ Department of Animal Husbandry, Agricultural Research Centre, 001200 Vantaa 30
}

\section{Esko Poutiainen}

Department of Animal Husbandry, University of Helsinki, 00710 Helsinki 71

\begin{abstract}
Comparisons were made between two groups of four Ayrshire calves, one group feeding on pasture and the other fed indoors on cut grass as the only food between $8-18$ weeks of age.

For determination of pasture grass intake of clipping method was compared with the indicator technique, chromium oxide being used as an indicator.

Studies on behaviour were made to clarify the development of the ruminating function of the calves as well as the effect of cut and pasture grass plus a concentrate supplement on their behaviour.

The digestibility of organic matter of pasture grass was $1-4 \%$-units higher than that of cut grass. Intake of grass indoors was approximately $1940 \mathrm{~g} \mathrm{DM}$ per animal per day. With the clipping method the average intake of pasture grass was $1355 \mathrm{~g}$ DM per animal per day and with the indicator technique $2061 \mathrm{~g}$. The latter value seemed to be nearer the correct one, if a conlcusion is to be drawn from the live weight gain of the calves.

Time used for intake of grass increased rapidly once the liquid feeding period was ended, that is during the whole experimental time up to eight of the 14.5 hours of the observation interval.

Calves at the age of $26-37$ days ruminated for approximately $116 \mathrm{~min}$ in eight hours. Supplementation of concentrates considerably decreased the time spent eating and increased the time spent ruminating by a small amount.
\end{abstract}

\section{Introduction}

As soon as a calf's rumen functions have developed, high quality animal protein required by a non-ruminant calf can be replaced with vegetable protein without any detrimental effect on the live weight gain of the animal. Diet has an important effect on the development of a calf's alimentary tract. If the allowance of liquid milk is restricted and hay as well as concentrate is offered from the first week of the calf's life, its rumen functions become fully developed by $6-8$ weeks of age (Roy $1970 \mathrm{~b}$ ).

1) Present address: Ypäjän maatalousoppilaitos, 32100, Finland

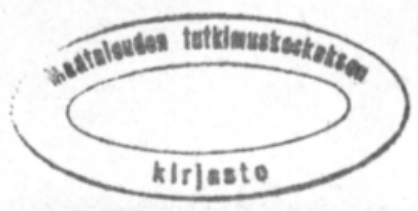


If the ruminant calf is raised mainly on pasture and corn concentrate the energy and protein content of grass at the pasture stage of growth or at the stage of growth prior to harvesting for silage meets it's nutritional requirement (Wilkinson and TAyler 1972, Poutiainen and Huilaja 1972). However, grazing behaviour and the physiological capacity of the calf's alimentary tract, which affects the digestibility and utilization of the feed, could limit growth. Young calves fed on good pasture and limited quantities of diluted milk concentrate have progressed as well as calves fed conventionally indoors (Chambers 1961, Meadowcroft and Turner 1971). In addition to grass, concentrates are recommended for the 1st 5-6 weeks of age (Roy 1970 a).

Experiments with older beef cattle have given comparable results between cut grass and grazed pasture (STEWART and McCUllough 1972, TURner 1972). It is due to herbage selection live weight gain per kilogram of dry matter has often been better with grazing than with cut grass feeding (MEYER et al. 1956). Contradictory results obtained with young calves (ALDER and CoPPER 1967) are thought to be due to young animals being very critical in diet selection (Hodgson and RodRIgUes 1971). Live weight gain per hectare has been calculated to be 20 to 40 percent higher for calves fed on cut grass than for those raised on pasture. Grasses selectively grazed differ in their composition and digestibility value from those harvested at the same stage of growth especially during mid and late summer (HARDISON et al. 1954) causing difficulties in the determination of the grazing intake. The clipping method, earlier in general use, does not give exact results so, at present, the indicator technique and eosophageal fistula methods are preferred (HodGson 1968).

The experiment reported here is a part of an extensive series of grazing and silage feeding experiments with cattle in which a special emphasis is placed on the use of grass as a protein source. The purpose of this work was firstly to investigate the ability of a young calf to use grass as its only nutrient other being fed a strict diet of diluted milk concentrate from birth to eight weeks of age and, secondly, to compare grazing with cut grass feeding. When determining the grass intake of grazing calves the clipping method was compared with the indicator technique. Observations of the behaviour of the calves were made in order that the development of ruminant functions and indoor and outdoor behaviour patterns could be followed.

\section{Materials and methods}

\section{Animals and management}

Eight male Ayrshire calves were divided into two groups of four. One group I a (of average age 58.0 days and live weight $61.6 \mathrm{~kg}$ ) was grazed on pasture and the second group I b (of average age $\mathbf{5 7 . 7}$ days and live weight $66.0 \mathrm{~kg}$ ) was fed cut grass.

In a parallel experiment two groups of 16 female Ayrshire calves of same age as male calves were treated as follows. II a) Grazed on pasture and fed $1.5 \mathrm{~kg}$ per calf per day of concentrated supplementary feed. II b) Fed cut grass and $3.0 \mathrm{~kg}$ per calf per day of concentrated supplementary feed. 
Before the experiment begun the calves received 4 litres of diluted milk concentrate, a maximum of $0.5 \mathrm{~kg}$ of hay and a maximum of $1.5 \mathrm{~kg}$ of concentrate $(40 \%$ barley, $40 \%$ oats and $20 \%$ protein concentrates) per animal per day. Water and a mineral vitamin mixture were freely available. Fresh herbage was first given to the individually tethered and fed calves at 6 weeks of age.

The groups I a and II a were turned out to graze on 30 June and the other two groups ( $\mathrm{I}$ b and $\mathrm{II} \mathrm{b}$ ) were fed cut grass indoors. A block grazing rotation was used with a complete rotation taking 5 days. Topping was performed on the day calves were moved from one plot to another - one half of each block being cut daily for the indoor fed group. The grass, water and mineral mixture were offered ad lib. to both groups.

\section{Composition of the grass}

The sward used was in it's fifth year and predominantly cooksfoot, in which there was plenty of weed. The cut grass and pasture grass were quite similar i their average chemical composition (Table 1).

Table 1. The average botanical and chemical composition of the herbage samples.

\begin{tabular}{|c|c|c|c|c|}
\hline \multirow{2}{*}{$\frac{\text { Botanical composition }}{\text { Plant species }}$} & \multirow[b]{2}{*}{$\%$} & & \multicolumn{2}{|c|}{ Chemical composition } \\
\hline & & & $\begin{array}{c}\text { cut grass } \\
\% \text { DM }\end{array}$ & $\begin{array}{c}\text { pasture grass } \\
\% \text { DM }\end{array}$ \\
\hline 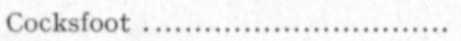 & 66 & Ash $\ldots \ldots \ldots \ldots \ldots \ldots \ldots$ & 8.7 & 9.2 \\
\hline Timothy ............................... & 7 & Crude protein ........ & 19.2 & 18.9 \\
\hline Other cultivated species ............ & 5 & Crude fat .............. & 4.3 & 4.1 \\
\hline 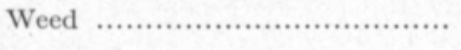 & 22 & Crude fibre $\quad . . . \cdots \ldots$ & 23.8 & 23.1 \\
\hline & & N-free extract $\ldots . .$. & 44.1 & 44.7 \\
\hline
\end{tabular}

\section{Determination of the intake and digestibility of herbage}

\section{Digest i bility}

The digestibility of cut grass was determined by the total collection method in two periods of ten days, between 19.-28. July and 18.-27. August. Preparation and chemical analysis of the feeds and faeces were made according to conventional methods. The digestibility coefficients were calculated according to the SUKO programme (AnON. 1971). The average age of the calves was 76 days at the beginning of the first collection period and 106 days at the beginning of the second.

The digestibility of pasture grass was determined by using the nitrogen content of the faeces as an indicator and applying an appropriate correction method (ANon. 1961). For the experiment the generally accepted equation $\mathrm{y}=6.11 \mathrm{X}+56.0$ (GReEnhalg and Runchie 1962), where $\mathrm{y}=$ digestibility of the organic matter in the herbage and $\mathrm{x}=$ nitrogen content of the faeces organic matter expressed as a percentage was used. For cut grass the in vivo digestibility of the organic matter (y) received by various calves and the mean values of the nitrogen content of the faeces $(x)$ were placed in the above equation and new values were calculated as standards in each collection period. 
Determination of the herbage intake

Intake of grass by the animals kept on pasture was determined by using, as an indicator, paper impregnated with $\mathrm{Cr}_{2} \mathrm{O}_{3}$. A dose of three grams of paper was given to each calf twice a day at $8.00 \mathrm{hr}$ and at $15.00 \mathrm{hr}$ together with five gram; of plastic granules of different colours for identifying the faeces. A spoonful of faecal samples was collected from each pale at $8.15 \mathrm{hr}$ and 21.00 hr. The daily faecal samples from each calf were preserved individually, by deep freezing. The chromium oxide content of the faecal organic matter was measured chemically.

Calculation of the organic matter in the faeces and the organic matter intake was made according to the following formulae using the digestibility index method, and correcting according to the faecal index method determined for pasture feeding (AnON. 1961).

$$
\text { Organic matter in faeces in } \mathrm{kg} / \text { day } \frac{\mathrm{g} \mathrm{Cr}_{2} \mathrm{O}_{3} \text { fed/day }}{\mathrm{g} \mathrm{Cr}_{2} \mathrm{O}_{3} / \mathrm{kg} \text { faecal organic matter }}
$$

Organic matter eaten in $\mathrm{kg} /$ day $=100 \times \frac{\mathrm{kg} \text { faecal organic matter } / \text { day }}{100-\text { digestibility } \% \text { of organic matter }}$

\section{Behaviour observations}

Behaviour observations were made on the 8 male calves (groups I a and I b) and 8 of the female of a similar age (groups II a and II b). The same observations were done on both sexes as separate but corresponding groups (Table 2).

Table 2. The observation periods and feeding regimes. The male calves were on pure grass diets and the female calves had $1.5 \mathrm{~kg}$ concentrate/head/day.

\begin{tabular}{|c|c|c|c|c|c|}
\hline Period & Date & Animals & $\begin{array}{l}\text { Age (days) } \\
\text { at the beginning } \\
\text { of observation }\end{array}$ & Die t & Time observed \\
\hline 1 & 25. -26.5 & $\begin{array}{r}4 \hat{\sigma}+40 \\
+\end{array}$ & 17.1 & $\begin{array}{l}\text { Diluted milk concent- } \\
\text { trate feed }\end{array}$ & $\begin{array}{l}2 \text { successive days, } \\
\text { during daylight } \\
\text { hours (à } 8 \mathrm{hrs} \text { ) }\end{array}$ \\
\hline 2 & 7. - 8. 6. & $4 \hat{\sigma}+40$ & 30.1 & $\begin{array}{l}\text { Diluted milk concen- } \\
\text { trate feed }\end{array}$ & $\begin{array}{l}2 \text { successive days, } \\
\text { during daylight } \\
\text { hours (à } 8 \mathrm{hrs} \text { ) }\end{array}$ \\
\hline 3 & $28 .-30.6$. & $4 \hat{\sigma}+40$ & 51.1 & Dry feeding & 48 hrs continuously \\
\hline $4 a$ & 31. 7. - 2. 8 & $4 \hat{\sigma}+4 \stackrel{+}{+}$ & 86.8 & Fed cut grass indoors & 48 \\
\hline $4 b$ & $2 .-4.8$. & $4 \hat{\sigma}+4 \hat{+}$ & 88.0 & Grazed on pasture & $\begin{array}{l}2 \text { successive days, } \\
\text { during daylight } \\
\text { hours (a } 8 \mathrm{hrs} \text { ) }\end{array}$ \\
\hline $5 \mathbf{a}$ & 29. -31.8 & $4 \hat{\sigma}+; 4^{0}$ & 115.8 & Fed cut grass indoors & 48 hrs continuously \\
\hline $5 \mathrm{~b}$ & 31. 8. - 2. 9. & $4 \hat{\sigma}+4 \hat{+}$ & 117.0 & Grazed on pasture & $\begin{array}{l}2 \text { successive days, } \\
\text { during daylight } \\
\text { hours }\end{array}$ \\
\hline
\end{tabular}


Observations were made on each individual at 5 minute intervals. The activity of each calf at the observation moment was marked on pre-punched data cards. Each action was assumed to occupy one observation period of 5 minutes. The activities were grouped as follows: nutritionel activities (eating concentrates, eating supplement feed, ruminating, drinking, licking), and non nutritional activities (standing, moving, lying). Simultaneous observations were made describing the activities of each experimental group.

\section{Results}

\section{Herbage digestibility}

The nitrogen content of the faecal organic matter of non-grazing calves was on an average $3.60 \%$ in the first collection period and $4.47 \%$ in the second. Digestibilites of the organic matter were $67.6 \%$ and $74.1 \%$ respectively. The equations according to the correcting method of GREENHALG and RUNCHIE (1968) for calculating the digestibility of organic matter by grazing animals were used. During the first collection period $\mathrm{y}=6.11 \mathrm{X}+45.6$ and during the second period $y=6.11 \mathrm{X}+46.8$. The nitrogen content of the faecal organic matter of the calves on pasture (during the first collection period approximately $4.22 \%$ and during the second period $4.66 \%$ of dry matter) was substituted in these equations. The digestibility of organic matter intake of pasture grass was calculated to be $71.4 \%$ and $75.1 \%$, respectively. These values were used when calculating the intake of pasture grass.

\section{Intakes of herbage by the clipping method and by the indicator technique}

According to the clipping method the quantity of fresh grass available varied from 6500 to 16500 kilos per hectare and the quantity of DM from 1360 to 2465 kilos per hectare respectively. From time to time more grass grew in the five day period than the animals were able to eat, which showed that the method did not give exact results under the conditions.

According to the indicator technique over $\mathbf{1 . 5}$ times as much of the organic matter intake of pasture grass was ingested than was the case with the clipping method (Table 3). The intake on pasture, determined by the indicator method, was noticeably higher than the intake of cut grass in both collection periods.

Table 3. Consumption of cut grass and pasture as determined by various methods.

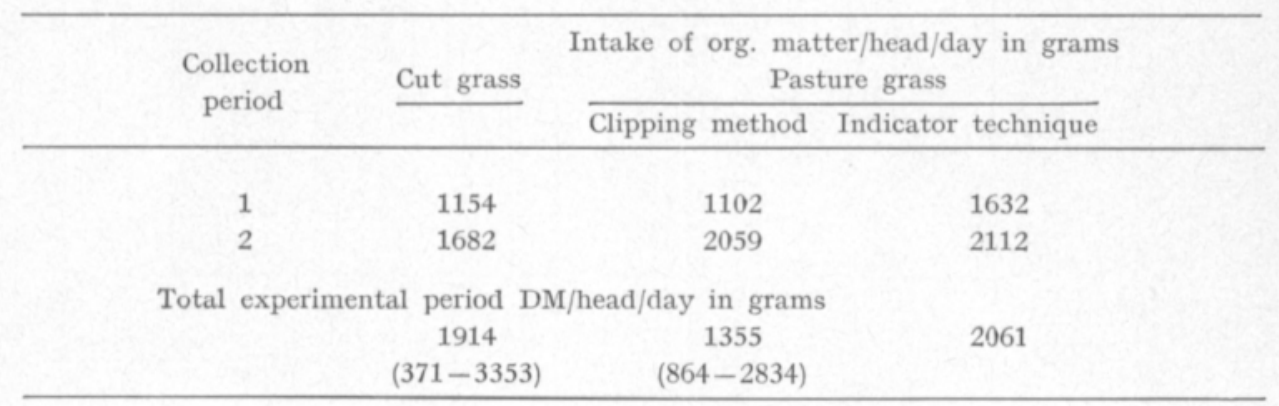


The live weight gain of the calves on pasture was on an average during the whole experiment $517 \mathrm{~g} / \mathrm{head} /$ day and of the calves fed indoors $375 \mathrm{~g}$, respectively. The live weight gain improved in both groups as the calves grew older.

\section{Behaviour}

Dvelopment of ruminant functions

Changes in the nutritional activities of calves during the liquid feeding period and after weaning are shown in fig. 1 .

Fig. 1. Changes in nutritional activities of the calves. The animals in group I were four male calves and in group II four female calves.

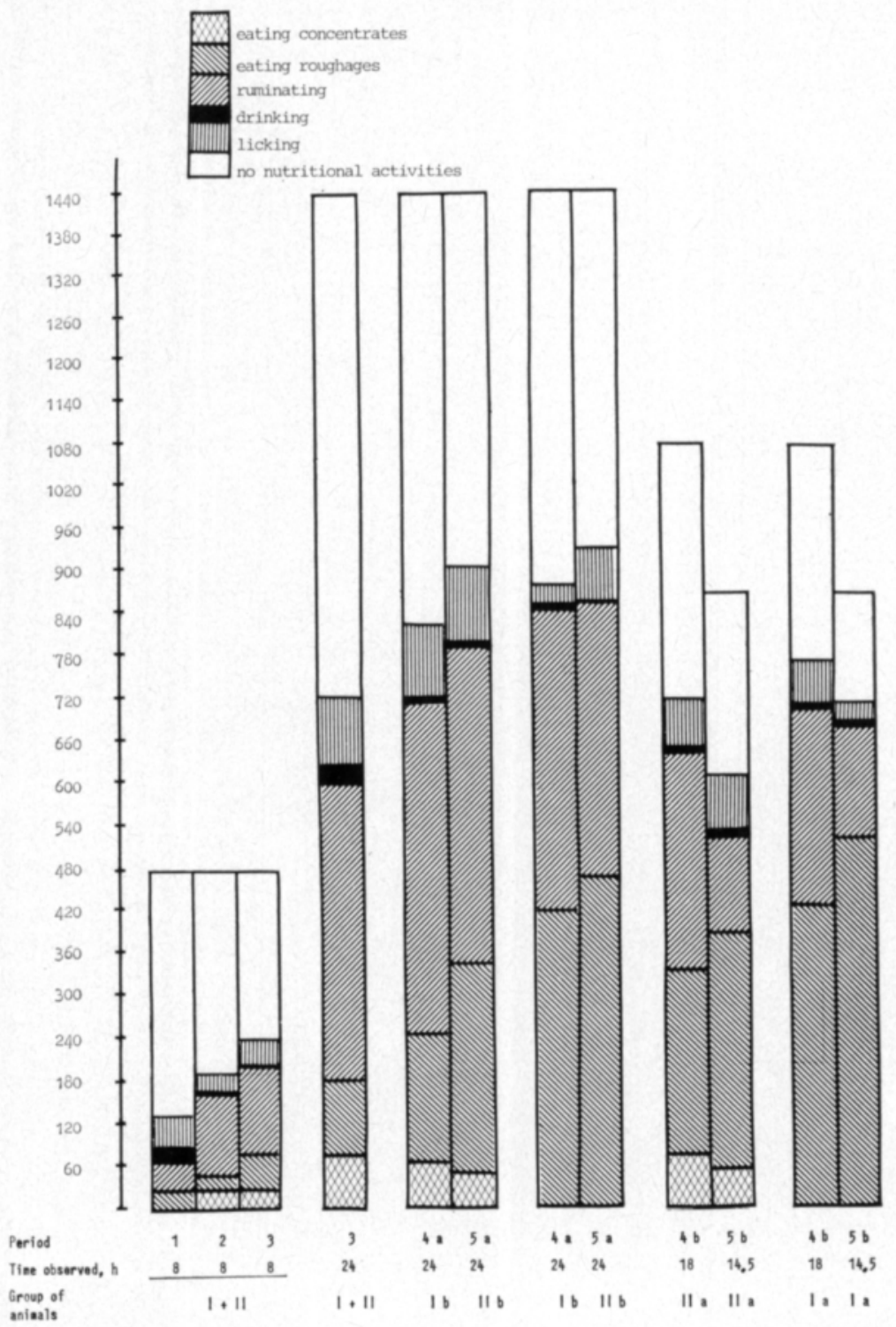


The differences in rumination time (5-85 minutes) between calves aged 13-24 days were significant during the first observation period. The rumination time does not seem to be linearly dependend on the calf's age. The calves aged $26-37$ days ruminated for $80-145$ minutes and during the third observation period the calves of an average age of $\mathbf{5 1 . 5}$ days ruminated for $115-150$ minutes.

On the basis of the time used for rumination the calf's rumen functions could be considered to be fully developed at least by the third observation period but in most cases by the second.

Both liquid feeding rounds were included within the observation period during the first and the second observation period. At first the calves drank from 5-40 minutes but during the second observation period, when only water was given the average drinking time was $8.1 \mathrm{~min}$.

During the first observation period only three calves ate concentrates (for 5-10 minutes in eight hours). During the second observation period intake of $1 \mathrm{~kg}$ of concentrate took from $10-45$ minutes. During the third observation period $1.5 \mathrm{~kg}$ of concentrate was consumed in the same length of time.

During the first and second observation period 21.3 and 17.5 minutes was spent eating roughage respectively. But during the third observation period 50 minutes was spent on eating roughage. Fresh grass was given as roughage during that period, some individuals eating for as long as $\mathbf{8 5}$ minutes, which is very near the time spent eating roughage by adult ruminants.

\section{A comparison of pasture with zero-grazing}

The third observation period continued for two days without a break. Results per day were calculated and the figures used as bases when comparing cut grass and pasture grass during the age period of 61-131 days (Table 4, Figure 1).

During the fourth observation period the calves on cut grass feeding and on pasture grass feeding ruminated for approximately the same time. The differences between individuals were smaller than during the previous observation period.

However, during the fifth observation period the calves on pasture ruminated for a very short time $-2.23 \mathrm{hrs}$ in $\mathbf{1 4 . 5} \mathrm{hrs}$. It is possible that they ruminated during the non-observation period in which case the differences were, in fact, smaller. Quality of the feed, time spent on eating and the rainy autumn weather may also have been factors affecting the time spent on rumination.

The rate of concentrate intake $(1.5 \mathrm{~kg} / \mathrm{animal} /$ day) increases as quickly on pasture feeding as on cut grass feeding from approximately $\mathbf{8 0}$ minutes to 50 minutes during the fifth observation period. The differences between the calves with the fastest and slowest rates of eating diminished from 65 minutes to 17.5 minutes.

The time spent drinking decreased as the calves aged and as the grass consumption increased. The calves receiving the concentrate on pasture licked less than the corresponding group fed indoors. The calves receiving only grass (indoors and outdoors) licked less than those receiving concentrates. 
Table 4. Results of studies on behaviour. The figures are averages (in minutes) per observation period.

\begin{tabular}{|c|c|c|c|c|c|c|c|c|c|c|c|}
\hline $\begin{array}{c}\text { Comparison } \\
\text { object }\end{array}$ & Period & $\begin{array}{l}\text { Time } \\
\text { hrs }\end{array}$ & $\begin{array}{l}\text { Age } \\
\text { days }\end{array}$ & Lying & Standing & Moving & $\begin{array}{l}\text { Eating } \\
\text { conc. }\end{array}$ & $\begin{array}{l}\text { Drink- } \\
\text { ing }\end{array}$ & $\begin{array}{l}\text { Ruminat- } \\
\text { ing }\end{array}$ & $\begin{array}{c}\text { Eating } \\
\text { roughage }\end{array}$ & Licking \\
\hline age & 1 & 8 & 17.1 & 284.3 & 184.3 & 11.3 & $2.5^{d}$ & $18.8^{e}$ & $44.4^{d}$ & $21.3^{d}$ & $50.6^{b}$ \\
\hline \multirow{2}{*}{ (indoors) } & 2 & 8 & 30.1 & 338.1 & 136.3 & 5.6 & $25.0^{\mathrm{e}}$ & $6.3^{d}$ & $116.3^{e}$ & $17.5^{d}$ & $37.5^{\mathrm{a}}$ \\
\hline & 3 & 8 & 51.1 & 313.1 & 156.3 & 10.6 & $25.0^{e}$ & $8.1^{\text {ed }}$ & $126.3^{e}$ & $50.0^{e}$ & $30.0^{\mathrm{e}}$ \\
\hline \multirow{3}{*}{$\begin{array}{l}\text { age } \\
\text { (indoors) }\end{array}$} & 3 & 24 & 51.1 & $1002.8^{f}$ & $388.1^{\mathrm{a}}$ & $49.1^{d}$ & $81.3^{e}$ & $20.6^{e}$ & 421.6 & $102.5^{d}$ & 97.7 \\
\hline & $4 a$ & 24 & 86.8 & $946.3^{\mathrm{e}}$ & $455.6^{d}$ & $38.1^{\mathrm{d}}$ & $33.4^{\mathrm{d}}$ & $12.2^{\mathrm{de}}$ & 448.1 & $302.8^{\mathrm{e}}$ & 65.9 \\
\hline & $5 a$ & 24 & 115.8 & $883.2^{\mathrm{d}}$ & $490.6^{\circ}$ & $66.2^{e}$ & $25.6^{d}$ & $4.6^{d}$ & 425.3 & $377.3^{e}$ & 82.1 \\
\hline \multirow{2}{*}{$\begin{array}{l}\text { indoor } v .^{1} \text { ) } \\
\text { grazing }\end{array}$} & \multirow{2}{*}{$4+5$} & 18 & 101.4 & $686.0^{\mathrm{a}}$ & $354.8^{d}$ & $39.2^{\mathrm{d}}$ & $22.1^{\mathrm{d}}$ & 6.3 & $327.9^{e}$ & $254.9^{d}$ & 55.5 \\
\hline & & 18 & 102.5 & $419.7^{d}$ & $566.2^{\mathrm{e}}$ & $94.1^{\mathrm{e}}$ & $34.6^{e}$ & 7.3 & $240.8^{d}$ & $436.6^{e}$ & 63.6 \\
\hline no concentrate & \multirow[b]{2}{*}{$4+5$} & 18 & 104.4 & $534.1^{\mathrm{e}}$ & $484.0^{b}$ & 61.8 & 0 & $4.6^{\mathrm{a}}$ & 277.3 & $431.1^{\mathrm{e}}$ & $42.9^{d}$ \\
\hline v. concentrate & & 18 & 99.5 & $571.2^{d}$ & $437.6^{a}$ & 71.5 & 56.7 & $9.0^{\mathrm{b}}$ & 290.9 & $259.9^{d}$ & $76.6^{\circ}$ \\
\hline cut grass & $4 a$ & 24 & & 995.6 & 398.1 & 46.3 & 66.9 & 15.0 & 470.0 & 188.1 & 99.4 \\
\hline v. concentrate & $5 \mathrm{a}$ & 24 & & 924.3 & 437.5 & 78.1 & 51.3 & 8.8 & 451.9 & 291.9 & 106.3 \\
\hline age & $4 a$ & 24 & & 896.9 & 513.1 & 27.5 & 0.0 & 9.4 & 426.3 & 415.6 & 32.5 \\
\hline (cut grass) & $5 \mathrm{a}$ & 24 & & 841.9 & 543.8 & 54.4 & 0.0 & 0.6 & 398.1 & 463.8 & 73.1 \\
\hline grazing & $4 b$ & 18 & & 511.3 & 483.3 & 85.6 & 76.3 & 5.0 & 305.0 & 258.8 & 73.8 \\
\hline v. concentrate & $5 \mathrm{~b}$ & 14.5 & & 268.1 & 513.1 & 86.3 & 50.0 & 10.6 & 134.3 & 338.1 & 74.4 \\
\hline age & $4 b$ & 18 & & 505.0 & 487.5 & 87.5 & 0.0 & 6.3 & 280.0 & 426.9 & 56.9 \\
\hline (grazing) & $5 \mathrm{~b}$ & 14.5 & & 263.1 & 526.9 & 77.5 & 0.0 & 3.8 & 169.4 & 512.5 & 30.0 \\
\hline
\end{tabular}

1) For statistical analysis observations have been calculated per $18 \mathrm{hrs}$.

Statistical differences $\mathrm{a}-\mathrm{c} \mathrm{P}<0.05, \mathrm{~d}-\mathrm{f} \mathrm{P}<0.01$

As the calves aged the time spent lying shortened. Those on pasture lay significantly less during the fifth observation period than those indoors.

Correspondingly the time spent standing, moving and on other activities, for inctance licking, increased more on pasture than indoors. The times spent by individual calves on these activities were very different. For instance, the time spent lying during the observation period varied by about 2.5 hours.

Concentrates clearly decrease the time spent eating grass for well fed calves on cut grass and on pasture. Therefore calves receiving concentrates had time to move, lie and socialise more than calves receiving only grass. The latter calves used almost $8 \mathrm{hrs} /$ day for eating and during the last observation period they spent $512.5 \mathrm{~min}$ of the $\mathbf{1 4 . 5} \mathrm{hr}$ period eating. The calves receiving concentrates ruminated approximately one hour longer than those on a pure grass diet.

\section{Discussion}

Experimental feeds and digestibility

On the basis of chemical analysis and digestibility experiments the herbage was satisfactory. At the start of the experiment, when the requirements of the calves for fodder were highest, the bulkiness of the herbage probably 
limited the intake and thus also growth of the calves. The protein content of the diet was sufficient according to the standards of RoY (1970 b).

Improvement in the digestibility of the cut grass during the second collection period was probably only due to the improvement of the quality of the herbage and not so much due to the fact that the calves were older.

Differences between digestibility of pasture and cut grass are expected as found in the relevant literature (HARDISON et al. 1954) and are significant enough to be taken into consideration when comparisons are made between performance on pasture and cut grass feeding.

\section{Herbage intake}

Herbage intake was rather small at the beginning of the experiment indicating that the food was not the best possible. The calves had no resort to closa cropping reducing the degree of herbage selection possible which, in turn, probably limited the grass intake on pasture (WILKINSON and TAYLER 1972, TAYLER 1966). The summer during which the experiment was performed was very warm and heat may have limited herbage intake on pasture (HAFEz 1969). With indoor feeding the quality rather than the quantity of herbage may have limited the intake.

Concentrate considerably shortened the time used for grass intake and the quantity of grass eaten. These results are in agreement with those of several other experiments (SLAdE 1972, Kossila and LAmpila 1974).

The experiment according to the index method has given very reliable results in comparison with those found in the appropriate literature. The method of collecting faeces from the pasture was time consuming and separation of plastic granules from faeces before further treatment was inconvenient. The chemical determination of chromium oxide was awkward. It would have been better to collect faeces over several successive periods, when digestibility could also have been determined by the slocal methods. Comparison of results from the two different methods also gave similar results to those found in the literature (RAYMOND et al. 1954).

\section{Behaviour}

The experiment on behaviour shows that even at the early age of one month Ayrshire calves have been able to fully utilize a grass diet. The ability to eat enough grass limits the live weight gain so much that it may be better to recommend additional concentrates between $0-4$ months of age. Similar results have been obtained in other experiments (Roy 1970 a, ANon. 1964).

On sparse pasture the times spent eating may limit the quantity of grass consumed. If it is too long it may decrease the rumination time, which may have an effect on the digestibility of the diet.

No remarkable differences were noticed between the feeding behaviour of calves on pasture and those fed indoors. However, calves on pasture spent more time on herbage intake than those fed on cut grass.

There were some differences in other activities between the grazing and zero-grazing groups which may have been dependent on external factors such as the need to move, weather conditions etc. 


\section{REFERENCES}

Alder, F. E. \& Cooper, E. M. 1967. Comparative studies of perennial ryegrass and cocksfoot as food for the calf. J. Agric. Sci. (Camb.) 68: 331-346.

Anon. 1961. Research Techniques in use at the Grassland Research Institute. Hurley. 166 p. I ed.

Anon. 1963. Farming at High Berkshire Mowthoope. 4. Ann. Rep. Nat. Agric. Adv. Service. Min. Agric. Fish. and Food.

- 1971. Sulavuuskoeohjelma SUKO. Moniste. Kotieläinhoidon tutkimuslaitos. Tikkurila, Finland.

Chambers, D. T. 1961. Grass as food for the calf. I. The value of cut grass in the diet of the unweaned calf in comparison with hay and concentrates. J. Agric. Sci. 57: 71-76.

Greenhalg, J. F. D. \& Runchie, K. W. 1967. The herbage intake and milk production of strip- and zero-grazed dairy cows. J. Agric. Sci. 59: 95-103.

Hafez, E. S. E. 1969. The behaviour of domestic animals. 647 p. 2. ed. London.

Hardison, W. A., Reid, J. T., Martin, C. M. \& Woolfolk, P. G. 1954. Degree of herbage selection by grazing cattle. J. Dairy Sci. 37: 89-102.

Hodgson, R. E. 1968. The relationship between the digestibility of a sward and the herbage consumption of grazing calves. J. Agric. Sci. (Camb.). 70: 47-51.

- - \& Rodriguez, J. M. 1971. The herbage intake of grazing calves. J. Brit. Soc. 26: 189 (Abst.).

Kossil.A, V. \& LAmpILA, M. 1974. Naudanlihan tuotanto vihreällä linjalla. Maataloustutkimuspäivillä pidetty esitelmä.

Meadowcroft, S. C. \& Turner, P. J. 1971. Beef from spring born calves. Exp. Husb. 20: 45-52.

Meyer, J. H., Lofgreen, G. P. \& Itrner, N. R. 1956. Further studies on the utilization of alfalfa by beef steers. J. Anim. Sci. 15: 64-74.

Poutiainen, E. \& HuilajA, J. 1971. Tillfredställandet av kalvarnas proteinbehov med ensilage. Nord. Jordbrusforskning 4: 337-338.

Raymond, W. F., Kemp, C. O., Kemp, A. W. \& Harris, G. E. 1954. Studies in the digestibility of herbage. J. Brit. Grassl. Soc. 9: 69-78.

Roy, J. H. B. 1970 a. The calf. Vol. I. Management and feeding. 183 p. 3. ed. London.

- 1970 b. The calf. Vol. II. Nutritional and health. 164 p. 3. ed. London.

SlADE, C. F. R. 1972. Effect of feeding concentrates to young grazing cattle. Exp. husb. 2: $60-68$.

Stewart, T. A. \& McCullough, J. J. 1972. Comparing methods of grass utilization for beef production. Agric. Nort. Ire. 47: 226-231.

TAYLER, J. C. 1966. A critical appraisal of pasture/animal relationships in the management of beef cattle. Ph. D. Thesiz. Univ. Reading (ref. WiLkinson, J. M. \& TAYLER, J. C. 1973).

TURNer, P. J. 1972. Zero grazing of young beef animals. Agric. 79: 476 -478.

Wilkinson, J. M. \& TAYLER, J. C. 1973. Beef production from Grassland. 118 p. I ed. London.

Ms received June 15, 1977 


\title{
Nuorten vasikoiden ruohon syönti ja käyttäytyminen laidun- ja niittoruokinnalla
}

\author{
PaAvo Tirhonen ${ }^{1}$ ) \\ Maatalouden tutkimuskeskus, Kotieläinhoidon Tutkımuslaitos, 01300 Vantaa 30
}

Esko Poutiainen

Helsingin yliopiston kotieläintieteen laitos, 00710 Helsinki 10

Kahdella neljä Ayrshire-sonnıvasikkaa käsittäneellä ryhmällä verrattiin laidunruokintaa ja vastaavan ruohon syöttämistä niitettynä sisällä ainoana rehuna $8-18$ viikon ikävälillä.

Laidunrehun syönnin määrittämisessä verrattiin näytealamenetelmää ja johtoainemenetelmää johtoaineena kromioksidi.

Niittoruohon sulavuus määritettiin kahtena kymmenen päivän jaksona käyttäen totaalista sonnankeruumenetelmää. Laidunrehun sulavuutena käytettiin sulavuuskokeen arvoja korjattuina sontaindeksillä, indikaattorina sonnan typpi.

Käyttäytymistutkimuksessa selvitettiin vasikoiden kehittymistä märehtijöiksi sekä niittoja laidunruohon ja väkirehun vaikutusta käyttäytymiseen. Juottoruokinnan aikana tarkkailtiin käyttäytymistä kahdesta kahdeksaan tuntia kahtena peräkkäisenä päivänä klo $8-16$. Myöhemmin tarkkailtiin kolmesti kuukauden välein kaksi vuorokautta yhtäjaksoisesti sisällä. Kahdella viimeisellä kerralla tarkkailtiin myös laitumella kahden peräkkäisen vuorokauden valoisana aikana.

Laidunruohon orgaanisen aineen sulavuudeksi saatiin 1-4\%-yksikköä korkeampia arvoja kuin vastaavan niittoruohon.

Sisäruokinnassa oli ruohon syönti keskimäärin koko kokeen aikana $1941 \mathrm{~g}$ kuiva-ainetta eläintä kohti päivässä. Keskimääräiseksi laidunruohon kuiva-aineen syönniksi eläintä kohti påivässä saatiin leikkuumenetelmällä $1355 \mathrm{~g}$ ja johtoainemenetelmällä $2061 \mathrm{~g}$. Vasikoiden kasvun perusteella arvioituna jälkimmäinen arvo on lähellä todellista kulutusta.

Keskimääräinen päivittäinen lisäkasvu oli sisäruokinnassa $375 \mathrm{~g}$ ja laitumella $527 \mathrm{~g}$. Rehun kulutus lisäkasvukiloa kohden oli niittoruoholla 4.46 ry ja laitumella leikkuumenetelmän mukaan 2.16 ry sekä johtoainementelmän mukaan 3.48 ry.

Vasikat märehtivät 26-37 päivån ikäisenä keskimäärin 116 min. kahdeksan tunnin aikana. Tämån jälkeen märehtimisaika lisäăntyi hyvin vähän sisäruokinnassa ja laitumella märehtimisaika lyheni viimeisellä tarkkailukerralla. Ruohon syöntiaika lisääntyi nopeasti juottoruokinnan päätyttyä ja sen jälkeen hitaammin koko koekauden ajan. Laitumella syőntiaika nousi aina kahdeksaan tuntiin asti tarkkailtujen 14.5 tunnin aikana. Väkirehulisä lyhensi huomattavasti ruohon syömiseen käytettyä aikaa ja lisäsi jonkin verran märehtimisaikaa.

Suoritettu tutkimus osoittaa, että ravintoarvoltaan tyydyttävällä nurmirehulla kasvutulos jää ilman väkirehua alle 4 kuukauden ikäisillä vasikoilla heikoksi niin laidun- kuin niittoruokinnallakin. Vasikan märehtijän ominaisuudet ovat kuitenkin jo sanotussa iässä hyvin kehittyneet ja edellytykset nurmirehun tehokkaalle hyväksikäytölle ovat olemassa.

1) Nykyinen osoite: Ypäjän maatalousoppilaitos, 32100 Ypäjä 